\title{
História sem Redenção: a oposição a Bossuet e a gênese da filosofia da história voltairiana
}

\author{
Edmilson Menezes \\ ed.menezes@uol.com.br \\ Universidade Federal do Sergipe, Aracaju, Brasil
}

resumo 0 presente trabalho busca explicitar alguns elementos da concepção voltairiana da história (e do historiador). A intenção não é a de inventariar, segundo uma ordem cronológica, a formação de uma filosofia da história em Voltaire, mas tão somente apresentar uma face dessa gênese, a saber, a crítica à teologia da história, que se encontra embasando aquele ponto de vista. Não há dúvida de que o erro faz parte do homem. Assim como a superstição, o fanatismo, o ódio, o crime, a guerra e todos os demais efeitos do erro. No entanto, à força de destruir o erro, a verdade foi cultivada. Com efeito, o combate ao erro é um impulsionador dos homens e semelhante guerra se passa na história: a história dos progressos do espírito. Não há uma condenação perpétua do homem à ignorância e, por isso mesmo, não faz sentido conceber a história a partir de uma redenção, que indica à humanidade sua incapacidade de encontrar, por si mesma, os caminhos da superação de seus erros. Uma história sem redenção; estamos diante de uma das ambições mais importantes do pensamento voltairiano. Com ela nasce o desejo de eliminar o miraculoso, o misterioso que envolve o entendimento da história, retirando-lhe a crença ingênua no fantástico, por um lado, e a névoa espessa que a culpa e a criminalidade original the impuseram, por outro. palavras-chave Voltaire; Filosofia da história; Teologia da história; Redenção; Progresso; Erro

O presente trabalho busca explicitar alguns elementos da concepção voltairiana da história (e do historiador). A intenção não é a de inventariar, segundo uma ordem cronológica, a formação de uma filosofia da história em Voltaire, mas tão somente apresentar uma face dessa gênese, a saber, a crítica à teologia da história, que se encontra embasando aquele ponto 
de vista. Não há dúvida de que o erro faz parte do homem. Assim como a superstição, o fanatismo, o ódio, o crime, a guerra e todos os demais efeitos do erro. No entanto, à força de destruir o erro, a verdade foi cultivada. Com efeito, o combate ao erro é um impulsionador dos homens e semelhante guerra se passa na história: a história dos progressos do espírito. Não há uma condenação perpétua do homem à ignorância e, por isso mesmo, não faz sentido conceber a história a partir de uma redenção, que indica à humanidade sua incapacidade de encontrar, por si mesma, os caminhos da superação de seus erros. Uma história sem redenção; estamos diante de uma das ambições mais importantes do pensamento voltairiano. Com ela nasce o desejo de eliminar o miraculoso, o misterioso que envolve o entendimento da história, retirando-lhe a crença ingênua no fantástico, por um lado, e a névoa espessa que a culpa e a criminalidade original lhe impuseram, por outro.

Voltaire, enquanto um marco na interpretação moderna da história ${ }^{1}$, travará uma batalha incessante contra a influência do mito, como acontecia nas narrativas dos antigos, tão apreciadas: "Será permitido a um homem de bom senso, nascido no século XVIII, nos falar seriamente dos oráculos de Delfos?" ou "nos dizer que as batalhas foram ganhas segundo as predições de Apolo, e fornecer como motivo o poder do diabo?" (VOLTAIRE, 1957, p. 43). De onde provém um erro tão funesto e tão geral? Da ignorância. (VOLTAIRE, 1963, p. 126). Um historiador que nos faça passar por verdadeiros tais absurdos, fala antes como crente do que como filósofo. A posição desse último é aquela que observará o passado com bom senso, ponderação racional e uma dose de sadio ceticismo. A fórmula atende estritamente às exigências dos novos tempos: "É certo, o conhecimento da natureza, o espírito céptico acerca das fábulas antigas honorificadas com o título de histórias, a sã metafisica separada das impertinências da escola, são fruto deste século, no qual a razão se aprimorou." (VOLTAIRE, 1957, p. 1568).

Separar, eis um verbo que ressoa como palavra de ordem. Com seu emprego, quer-se estabelecer nítidas fronteiras entre o que advém da razão e do cálculo e aquilo que na religião parece incongruente, tudo o que é mistério indecifrável. Desde Bacon e Locke, passando por Galileu e Descartes, há um vivo interesse entre os pensadores modernos em dessacralizar as ideias e as práticas. A ciência não tem que justificar suas 
diferenças com a Revelação; são as verdades reveladas, ao contrário, que devem passar pelo crivo da razão. Pode um mínimo de racionalidade aprovar aquilo que nas igrejas se brada contra os progressos dos conhecimentos humanos? A inteligência é a fonte de conhecimento e o fiel da balança quando se trata da organização das gentes, sua ação é púbica, passível de discussão e aprovação; à revelação, por sua vez, caberá "a câmara escura do coração" (AGOSTINHO, 1841), o reduto do privado. A consciência moral se limita a uma necessidade de organizar a vida em sociedade. "Um dos grandes males, como um dos grandes ridículos do gênero humano, é ver, em todos os países que chamamos civilizados, talvez com exceção da China, os padres se encarregarem daquilo que é de única competência dos filósofos." (VOLTAIRE, 1879, Article Philosophie). Se a ciência fazia grandes avanços na separação da fé, ainda restava uma semelhante tarefa a ser feita no domínio da história. Alijada do campo da ciência, ela recaiu nos braços da sublime teologia e necessitava, agora, passar por uma severa crítica e, dessa forma, reagrupar-se entre os saberes dignos de credibilidade racional. Para Voltaire, essa é uma empreitada da competência da filosofia.

Há uma má metafísica, à qual se opõe uma sã metafisica, isto é, uma metafísica depurada da presunção de ir além das possibilidades estabelecidas pela razão humana. Sob o abrigo da metafísica encontram-se temas trans naturam, que podem não ser coisa alguma. Contudo, esses temas, de uma forma ou de outra, nos interessam, como no caso da divindade: "Deus, que conhecemos por suas obras, mas que nosso orgulho quer definir; Deus, do qual sentimos o poder imenso; Deus, separado de nós pelo abismo do infinito e cuja natureza ousamos sondar." (Id. ibid., Article Métaphysique). A metafísica vinculou-se de tal forma à religião, que as fronteiras entre ambas restavam indiscerníveis. $\mathrm{O}$ apelo é para que o metafisico abandone o que não pode discernir com justeza e reserve-se o direito a "uma metafísica do ignorante ou da ignorância"2, feita de dúvidas, de probabilidades, sinônimo de não acomodação da inteligência; muito diferente do outro sentido de ignorância, também utilizado por Voltaire, para definir um estado de atraso e de incompreensão. Reconhecido esse ponto, outra figura toma o lugar do metafísico, a saber, o filósofo, ou seja, aquele que trabalha racionalmente em prol da humanidade, mas absolutamente cônscio de que trabalha com uma sã metafísica: "o filósofo não é entusiasta, não se erige em profeta, não se diz inspirado dos deuses.” (Id. 
ibid., Article Philosophe). A metafisica toma parte na grande tarefa entregue à filosofia: "para Voltaire, ela se apresenta, primeiramente, como uma atitude mental que investe e penetra em todos os aspectos da realidade, mais do que uma ciência que permanece no aprofundamento do plano teorético" (BENELLI, 2000, p. 18). ${ }^{3}$ Isso significa uma subordinação de todo o pensamento a esse princípio de inteligibilidade do real, de tal modo que essa noção não pareça estrangeira nem ao homem, nem ao mundo, aos quais ela comunica sua própria orientação. O resultado é que todo o peso desse pensamento recai sobre pontos precisos da história. Por isso, cabe à filosofia fornecer outros parâmetros de compreensão capazes de isolar a recomposição do passado do contágio mítico exercido pelo trabalho inconsistente dos historiadores, muitos deles associados ao cristianismo. Era necessário uma descristianização da história.

Ao reconstituir a história, o historiador contribui para o esclarecimento dos povos, porque "os que esclarecem (détrompent) os homens são seus verdadeiros benfeitores.” (VOLTAIRE, 1963, p. 126). Com efeito, se os verdadeiros benfeitores da humanidade são os que lhe esclarecem, falar da história de forma mítica não traz nenhum beneficio, pois em nada ajuda para o conhecimento dos homens reais. Pelo contrário, ela lhes prepara o sentimento para a aceitação de desígnios estranhos, preestabelecidos, para a conformação e para o ato resignado. A história informada pela mística é o maior exemplo do cultivo desse sentimento. Uma "história santa" sofre da mesma falha que uma filosofia subordinada à teologia: "falta-lhe o imprevisto" (POMEAU, 1963, p. 29). Ela já está feita, só resta seguir-lhe. Uma visão religiosa do mundo prende a história à rota de um caminho inapelável, eliminando qualquer possibilidade de independência, já que o desvio original conduziu à tutela providencial; é o que acontece no Discours sur l'Histoire Universelle, onde Bossuet, por estar preso à orientação pétrea de uma história sagrada, faz cortes propositais em fatos importantes, esquece outros e abusa da exaltação ao povo ocidental (cristão):

"O ilustre Bossuet que no seu Discurso sobre uma parte da História Universal apreendeu-lhe o verdadeiro sentido, ao menos no que ele diz acerca do império romano, detém-se, no entanto, em Carlos Magno. (...) Esse eloquente escritor, referindo uma palavra sobre os árabes, que fundaram tão poderoso império e uma religião florescente, não os trata a não ser como um dilúvio de bárbaros. Ele parece ter escrito 
unicamente para insinuar que tudo foi feito no mundo tendo em vista a nação judia; se Deus deu o império da Ásia aos babilônicos, foi para punir os judeus; se Deus fez reinar Ciro, foi para os vingar, se Deus enviou os Romanos, tal foi ainda para castigá-los. Tudo isto pode ser, mas as grandezas de Ciro e dos Romanos têm ainda outras causas." (VOLTAIRE, 1963 p. 1963).

A parcialidade do bispo de Meaux reflete a forma como a teologia concebe o tempo e o mundo: a escolha de um povo para exemplificar o mandato divino, exclui todos os outros e esconde o que neles há de melhor e superior. Além do partido em prol de um grupo, Bossuet arvora-se em intérprete do invisível manifestado na história: "os impérios do mundo serviram à religião e à conservação do povo de Deus” (BOSSUET, 1966, p. 351), diz ele; os reinos convieram à reverência e à instrução "não somente dos grandes príncipes (...), mas, ainda, àqueles particulares que contemplam, nesses grandes objetos, os segredos da divina Providência." (Id. Ibid., p. 349). A história universal é transformada na história do povo cristão:

"Sob o poderio dos Romanos, os Judeus duraram até Jesus Cristo.

Quando eles o desconheceram e o crucificaram, esses mesmos Romanos emprestaram suas mãos, sem o saberem, à vingança divina e extirparam aquele povo ingrato. Deus, que havia deliberado reunir - no mesmo tempo - o novo povo de todas as nações, reuniu, primeiramente, as terras e os mares sob esse mesmo império. $\mathrm{O}$ comércio entre tantos povos diversos, antes estrangeiros entre si, e depois reunidos sob a dominação romana, foi um dos mais poderosos meios dos quais se serviu a Providência para abrir caminhos ao Evangelho." (Id. ibid.).

A dominação romana sobre os judeus, assim como sobre outros povos, possui um contexto e uma série de motivos verificáveis racionalmente e atestados por tudo o que ficou de documentação, vestígios e monumentos espalhados onde o império dos Césares se estendeu. Bossuet, enquanto historiador cristão, trai a evidência dos fatos, ofende a razão e o interesse da verdade. A sucessão dos impérios, descrita sob tal prisma, aparece eivada de uma visibilidade especial; lá se encontra a marca da providência na consecução de seus planos. Ela anula qualquer iniciativa humana original e dissolve qualquer interesse racional em recompor o passado. 


\section{4}

Ao ler os historiadores, Voltaire tem a impressão de que a terra não foi criada senão para alguns soberanos e para aqueles que serviram às suas paixões; quase todo o resto é abandonado. Nisso, tais cronistas assemelham-se a alguns tiranos dos quais falam: aqueles sacrificam o gênero humano por causa de um só homem ou de um só povo. Os historiadores cristãos são um exemplo disso.

"O que mais admiro em nossos modernos compiladores é a boa fé com que nos provam que tudo o que aconteceu no passado nos maiores impérios do mundo só aconteceu para instruir os habitantes da Palestina. Se os reis da Babilônia, em suas conquistas, caem ao passarem sobre o povo judeu, é unicamente para corrigir esse povo de seus pecados. Se o rei chamado Ciro torna-se senhor da Babilônia, é para dar a alguns judeus a permissão de retornarem ao seu país. Se Alexandre é vencedor sobre Dario, é para estabelecer negociantes em Alexandria. Quando os romanos acrescentam a Síria ao seu vasto domínio e englobam o pequeno reino da Judéia ao seu império, ainda é para instruir os judeus. Os árabes e os turcos vieram apenas para corrigir esse povo amável. É preciso admitir que houve uma excelente educação; jamais tivemos tantos preceptores - eis como a história é útil!" (VOLTAIRE, 1879, Article Histoire).

A exposição crítica dos quadros referenciais de interpretação da história é acompanhada de uma redefinição de seu campo cronológico e espacial. A história deve abarcar os povos mais antigos, indianos e chineses, por exemplo, de forma a que tenhamos, verdadeiramente, uma história universal, ou seja, uma história da humanidade. Somente desta forma a história poderá se dizer útil: "Qual a história útil? Aquela que nos mostra nossos deveres e direitos sem ter a aparência de nos querer ensiná-los.” (Id. ibid.). A história põe-se, com Voltaire, a serviço da construção de um novo homem, do homem moderno: aquele que já não aceita receber as suas normas e leis nem da natureza das coisas, nem de Deus, mas que pretende escolhê-las e fundamentá-las ele próprio a partir de sua razão e da sua vontade. A ideia de história em Voltaire, aplicando ao entendimento do mundo a convicção de que o homem é o princípio de toda a historicidade, tomará como norte o fato de que a humanidade é a autora e a aprendiz de sua própria trajetória. O movimento, aqui, é duplo: escrevendo para uma 
elite cultivada, distinguida por sua adesão mais ou menos consciente a um conjunto de valores, de costumes e de hábitos intelectuais, o Patriarca de Ferney conceberá uma ideia de homem que aglutinará, como expoente máximo, todo o movimento da história. Aqueles que sabem, que colocam as questões, que possuem iniciativa nas diversas matérias, alimentam-se do conceito de homem formulado pelo filósofo. Eles se reconhecem como aqueles a que o tempo colocou numa condição de uso da razão como guia seguro e apropriado para torná-los senhores de seus destinos, sem entregá-los a um poder distante que, por isso mesmo, é sagrado e ausente dos assuntos terrenos.

A filosofia do mundo moderno propicia todas as condições para uma ruptura entre a história e a teologia. Às interpretações religiosas da história, doravante desqualificadas, sucedem novas propostas. A ideia de uma humanidade histórica, concebida porVoltaire, é um dos marcos dessa mudança; ela constitui a referência a uma concepção de tempo centrada inteiramente no homem enquanto influente. Nada mais de subordinação a nenhuma espécie de plano oculto, mas esclarecimento das possibilidades da inteligência alcançar os seus propósitos por si só, a natureza tudo pôs ali para que o sucesso fosse alcançado. Não se pode conceber um futuro para a comunidade dos homens sem a situar em relação a tudo aquilo com o qual ela coexiste, e que é fruto da experiência passada. Presente, passado e futuro não se estruturam num discurso lógico e coerente a partir do centro providencial, porém, a ação humana, a construção do mundo pelas mãos visíveis de seus habitantes, é o referencial para qualquer análise do tempo.Voltaire tem a consciência de que esse é um produto moderno:

"Uma ordem inteira de religiosos abolida pelo poder secular, a disciplina de algumas outras ordens monásticas reformadas por esse poder, as divisões entre toda a magistratura e a autoridade episcopal, fizeram ver o quanto de pré-julgamentos foram dissipados, o quanto a ciência do governo se expandiu e a que ponto os espíritos se esclareceram. As sementes dessa ciência útil foram lançadas no último século; elas germinaram por todos os lados neste, até o fundo das províncias, com a verdadeira eloquência, dantes só conhecida em Paris (...). Uma razão superior se fez entender nesses últimos tempos (...).A filosofia, ao tornar o espírito mais justo, e ao banir o ridículo dos adornos rebuscados, tornou mais de uma província adversária da capital." (VOLTAIRE, 1957, pp. 1566-1567). 


\section{6}

O tempo não mais aparece como um sucedâneo da eternidade. As condições estão dadas para que nasça uma filosofia da história e mesmo para uma filosofia das Luzes" ${ }^{4}$ :

"Em todas as nações a história é desfigurada pela fábula, até que, enfim, a filosofia venha esclarecer os homens; e quando, afinal, a filosofia chega ao núcleo dessas trevas, encontra os espíritos tão ofuscados por séculos de equívocos, que somente a muito custo pode destruir os erros; ela encontra cerimônias, fatos, monumentos estabelecidos para respaldar as mentiras." (VOLTAIRE, 1963, p. 801).

A tarefa da filosofia se amplia como filosofia da história e sua função é a de traçar e combater erros perpetrados pela ignorância dos povos ao longo dos séculos, ou seja, ela deve ser capaz de revisitar o passado humano em vista do próprio esclarecimento do homem. E, nessa direção, podemos afirmar que a filosofia da história, em Voltaire, nasce a partir de uma ocupação do espírito voltada para a análise dos prejuízos trazidos ao gênero humano pelo obscurantismo; sobretudo, nasce como uma crítica que se depara e luta contra a fábula e o mítico na história, enquanto entrave ao esclarecimento. Do mesmo modo, ela combate o desdobramento desse aspecto obscuro, a saber, a teologia: "Talvez a maior reprovação que eu mereça seja a de ser um filósofo livre (...). Acreditei prestar um serviço ao espírito humano ao mostrar o fanatismo exacerbado e as disputas teológicas ridículas (...)." (VOLTAIRE, 1975, pp. 579-580). Nessa última cena concentra- se o conjunto antípoda da filosofia da história: imprecisão, crença cega e inflexibilidade espiritual. A oposição à doutrina da providência, enquanto conceito nuclear da teologia da história,é uma clara manifestação da atitude crítica voltairiana. Libertar a história das peias da teologia é libertar o homem da superstição e, assim, ultrapassar o tempo mítico que ficou para traz, pois incompatível com os avanços da ciência e dos costumes presenciados pela modernidade. A civilização, isto é, atividade agrícola, movimento do comércio, avanço dos negócios, prosperidade das letras e das artes, à qual não se pode renunciar sob pena de renunciar às conquistas humanas, obedece e reflete o próprio desenvolvimento histórico: corpos e mentes humanos se modificam ao longo do tempo, as evidências e as exigências da humanidade se renovam com a renovação da civilização. 
O que permanece é a condição racional dessa mesma humanidade e sua capacidade de perfectibilidade.

A qualidade do conhecimento melhora nos países e nos tempos em que a civilização pôde se desenvolver. A história da história coincide com a história do homem, é o que tenta mostrarVoltaire. Se tomarmos o artigo História, da Enciclopédia, nele registra-se um mesmo movimento: "os progressos da epistemologia da história e as grandes linhas da história universal.” (DAGEN, 1977, p. 13). Com efeito, uma adesão à ideia de progresso não se coaduna com a fé cristã, antes mesmo a ela se opõe. A Voltaire cabe o mérito não só de fundar a expressão "filosofia da história" ${ }^{5}$, mas, do mesmo modo, de propor uma reflexão filosófica para a história. A expressão entrará para a "história das terminologias" (KOSELLECK, 1979, p. 647) e a filosofia da história caracterizará uma busca pela unidade inerente à sucessão das gerações humanas a partir dos componentes provenientes da própria história. O conteúdo conceitual, estranho ao campo semântico tradicional da palavra, exige uma denominação original; o termo já nasce com uma carga polêmica ${ }^{6}$ : ele se volta, do ponto de vista crítico, contra a crença nas Escrituras e, do ponto de vista metafísico, contra a providência divina que, segundo a explicação teológica, funda uma coerência inerente às histórias.

Nesse sentido, um inimigo privilegiado é escolhido:Voltaire combate Bossuet. Talvez essa represente uma das batalhas mais expressivas do período de afirmação da filosofia das Luzes. De um lado, o Discours sur l' histoire universelle (1681), de Bossuet; de outro, o Essai sur les moeurs (1756), de Voltaire. A diferença já se encontra na primeira palavra, de parte a parte, em cada um dos títulos. Bossuet escreve um Discurso, quer dizer, ele acredita ser possível submeter a matéria da história universal a uma ordem retórica pré-determinada.Voltaire não possui essa destemida certeza: ele escreve um Ensaio, segundo um modo não definitivo. $O$ ensaio é o lugar de uma intensa inventividade, ele não cessa de pretender reinventar as regras de sua escrita numa grande liberdade formal. "O Ensaio pode ser globalmente caracterizado como um conjunto de estratégias formais de sedução do leitor." (BIZIOU, 1997, p. 429). Se o termo é empregado e valorizado, o é em oposição ao Discurso, ao Tratado - acusados de serem mais formais, pesados. "Intitular seu livro 'Ensaio', é prometer ao leitor que algo vai ser ensinado, todavia, isso não será maçante.” (Id. Ibid.). No 


\section{8}

ensaio, encontra-se reunida uma série de elementos que modificam o que se espera de um leitor. Se no discurso sua leitura é passiva, no ensaio ele é tido como uma figura inteligente, aberta e, principalmente, ativa:

"Os livros os mais úteis são aqueles que os leitores fazem, eles próprios, a metade; entendem os pensamentos que lhes apresentamos em germe; corrigem o que lhes parece defeituoso, e fortificam, por suas reflexões, o que lhes parece fraco." (VOLTAIRE, 1879, Préface).

Daí provém, então, a fórmula que determina a grande aceitação do ensaio como forma, no Século XVIII: o prazer da leitura liga-se à instrução. "O ensaio reivindica para as Letras, porque doravante laicizada e estendida a todos os domínios da sociedade, uma nova utilidade social." (BIZIOU, 1997, p. 429). Contudo, enganar-nos-íamos se entendêssemos, aqui, apenas uma questão de estilo literário. $\mathrm{Na}$ verdade, a forma, nesse caso, subordina-se a uma disputa filosófica: está em jogo a noção de história e sua condução.

Por meio de um "maravilhoso encadeamento", Bossuet faz remontar a tradição da Igreja até as origens do mundo e acrescenta aos espíritos ávidos de certezas:

"Que consolação para os filhos de Deus! Que convicção da verdade, quando eles veem de Inocêncio $\mathrm{XI}^{7}$, hoje ocupando tão dignamente o primeiro assento da Igreja, remontarmos, sem interrupção, até São Pedro, estabelecido por Jesus Cristo príncipe dos apóstolos; de onde seguimos, ao retomarmos os pontífices que serviram sob a Lei, até Arão e até Moisés; daí até os patriarcas, e até a origem do mundo! Que sequência, que tradição, que maravilhoso encadeamento! Se nosso espírito naturalmente incerto, e transformado pelas suas incertezas em joguete de seus próprios raciocínios, tiver necessidade, nas questões atinentes à salvação, de ser fixado e determinado por alguma autoridade certa, qual maior autoridade do que aquela da Igreja católica, que reúne nela própria toda a autoridade dos séculos passados e as antigas tradições do gênero humano, desde sua primeira origem?” (BOSSUET, 1966, p. 338 - grifo nosso).

Nada pode mudar os séculos passados e todo o passado humano pertence “à única Igreja católica [que] preenche todos os séculos precedentes" (Id. 
ibid., pp. 339-340) e, se "é esse passado que nos assegura o futuro" (Id. ibid., p. 341), nos é permitido entender que a história é a sequência da Igreja.Tal sucessão compreende a orientação dos espíritos incertos, sua instrução; para tanto, trava-se uma luta, desde sempre, com "a falsa ciência", com a impiedade. A guerra objetiva centrar o mundo sob a tutela da Igreja. Uma doutrina da história é requerida para fazer convergir para o Cristo e para a religião cristã, "tão antiga quanto o mundo" (Id. ibid., p. 340), toda a inteligibilidade da sucessão dos tempos. Essa inteligibilidade é garantida em função de um universal, isto é, da ordem e da sequência compreendidas pelo pensamento de tudo que há de grande entre os homens, estabelecido graças à submissão de todas as demais manifestações do espírito humano à catolicidade cristã.

"Aqui tombam aos pés da Igreja todas as sociedades e todas as seitas que os homens estabeleceram dentro ou fora do cristianismo. Por exemplo, o falso profeta dos Árabes bem pôde se dizer enviado de Deus, e, após haver enganado os povos ignorantes, pôde usufruir das divisões de sua vizinhança, para aí estabelecer pelas armas uma religião totalmente sensual; porém, ele não ousou supor que era esperado, nem pôde dar, enfim, ou à sua pessoa, ou à sua religião, nenhuma união real nem filiação aos séculos passados." (Id. ibid., pp. 338-339).

Os acontecimentos do mundo antes e depois do Cristo podem parecer desconformes aos olhos sem fé, mas eles são apenas o quadro exterior da história da salvação. Sua importância ou sua irrelevância são avaliadas a partir do prisma da redenção. Assim, os árabes, e tantos outros pagãos situam-se naquela irrelevância e são objeto da invisível providência na condução da história.

O bispo de Meaux sintetiza toda uma tradição teológica iniciada por um outro prelado, o de Hiponna. A despeito de suas grandes diferenças, os dois doutores concordam nos seguintes pilares: a dimensão histórica é essencial à religião, a história é a história da salvação e a providência não se atém ao caso particular, mas o envia ao acordo com as disposições gerais da economia salvífica; a teologia da história está diretamente ligada à teologia da graça, que salvaguarda, ao mesmo tempo, a onipotência divina e a liberdade humana: os maus, fazendo o que eles querem, só fazem aquilo que Deus lhes permite fazer, e, assim, não saem da ordem maior; a convicção comum de que a causalidade divina, longe de negar 
as causalidades naturais, fundamenta essas mesmas causalidades (é segundo a presciência de Deus que alguma coisa depende de nossa vontade, diz Santo Agostinho ${ }^{8}$ ), o que torna uma história providencial, não só possível, como também respaldada por um discurso lógico; enfim, a comum consideração da história em sua universalidade: as partes ganham sentido unicamente em relação ao todo. Uma concepção estética da história ${ }^{9}$ se forma, ou melhor, uma concepção estético-teológica molda a história: "à maneira de um quadro assentado, com suas tintas sombrias, num bom lugar, assim também o conjunto dos seres, se ele pode ser abarcado num olhar, permanece belo, mesmo com os pecadores (...)." (AGOSTINHO, 1841, XI, p. 23). Bossuet retoma a metáfora pictórica, ao afirmar a história como certos quadros, que aparecem com muita frequência nas bibliotecas dos colecionistas como um jogo de perspectiva; inicialmente eles parecem-nos confusos, mas, tão logo aquele que conhece o segredo nos faz olhá-los por certo ângulo, imediatamente todas as linhas desiguais se reagrupam e toda a confusão se desfaz. (BOSSUET, 1961, pp. 1061-1062). A história é uma anamorfose da qual Jesus Cristo é o ponto. (FERREYROLLES, 1982, p. 241).

A possibilidade de uma interpretação cristã da história não se funda nem sobre o conhecimento de valores espirituais, nem sobre a intuição de que Jesus foi um indivíduo de importância histórica, pois vários indivíduos destacaram-se na história do mundo e mais de um se fez passar por um redentor. A interpretação cristã da história sustenta-se da suposição que Jesus é o Cristo, quer dizer, encontra sua base na doutrina da Encarnação. A afirmação que faz repousar o sentido total e único da história antes e após o Cristo sobre a vinda histórica de Jesus Cristo é estranha ao espírito moderno, do qual Voltaire permanece um dos maiores representantes. Para esse último, o Cristo da história não tem nada de transcendente; ele foi um judeu provindo da escória do povo, filho reconhecido de um carpinteiro provinciano, um camponês grosseiro da Judéia, embora, sem dúvida, mais esperto. Como atacava os sacerdotes, esses constrangeram Pilatos a prendê-lo. ${ }^{10}$ Jesus não foi o fundador do cristianismo, mas um teísta. Ele foi um entre essas gentes da ralé, de onde vêm os profetas judeus, que se destacou do populacho e fez mais barulho, por isso transformado em deus. ${ }^{11}$ "Ele fazia pouco caso das superstições judaicas. Teísta israelita, como Sócrates foi um teísta ateniense, (...) ele não instituiu nada que 
tivesse a menor relação com o dogma cristão; jamais pronunciou o nome cristão." (VOLTAIRE, 1879, p. 69).

O Advento, por conseguinte, é ridiculamente presunçoso porque empresta a um grupo insignificante de judeus e de cristãos uma importância cósmica, lembra Löwith. (LÖWITH, 1983, p. 198). Para Voltaire, ele é do mesmo modo ridículo porque eclipsa a história das civilizações ao basear-se numa fábula, cuja reconstituição, dada pelas Escrituras, é contraditória, errônea e infantil. No fundo, o cristianismo, iniciado pelos discípulos do Cristo, produziu, como dantes nunca visto, um fanatismo digno de horror e desprezo que se transformará em doutrina.

O Discours sur l'Histoire universelle aplicou ao domínio da história essa mesma certeza dogmática. Uma armadura doutrinária fornece suporte às configurações da inteligência e o indivíduo é tão somente um ponto secundário de aplicação de uma verdade cuja origem e o fim situam-se em Deus. Legítima representante do classicismo francês, ela reproduz, em grande parte, uma ideia de humanidade originada de um único ancestral e, com isso, toda a história será aquela de um povo transformado no emblema da salvação.

"Em Bossuet, a Igreja e o Estado, a religião e o governo político se completam mutuamente e, ao menos em princípio, a história sagrada é a mais importante. Em Voltaire, a Igreja e a religião estão submetidas ao Estado. Ao rejeitar a Providência, o indivíduo se liberta." (FERENCZI, 1984, p. 190).

Voltaire tenta mostrar que é impossível organizar qualquer tipo de justificativa metafisica para estabelecer isenção ou culpa divinas diante de determinados acontecimentos, como por exemplo, o terremoto de Lisboa (1755): No Poème sur le Désastre de Lisbonne, o filósofo registra a ignorância do homem, a descrença na Providência e a impossibilidade de alguma doutrina explicar o mal.

O autor do Cândido elimina da história toda finalidade providencial. Os acontecimentos "são o efeito necessário de leis eternas e necessárias". (VOLTAIRE, 1963, p. 915). Não podemos nos colocar no ponto de vista divino, mas somente relacionar o curso dos fatos a causas verificáveis. Acreditar na Providência é renunciar à razão e preferir a ingenuidade cega, como aquela que o eremita tenta insuflar em Zadig, no conhecido conto: 
“- Tu me havias prometido mais paciência (...) Pois fica sabendo que, debaixo das ruínas dessa casa que a Providência incendiou, o proprietário encontrou um tesouro imenso; e é bom que saibas que esse jovem, a quem a Providência torceu o pescoço, teria assassinado a sua tia dentro de um ano, e a ti daqui a dois anos." (VOLTAIRE, 2005, p. 140).

A Providência não poderá continuar como "autor das grandes séries dos acontecimentos humanos": é imperioso reduzir o poder providencial para, assim, colocar o homem à vontade consigo mesmo, descobri-lo como condutor de sua história. Quando a religião é, criticamente, elucidada pela história, ela nada mais faz do que ser situada no plano da cultura e dos costumes; todavia, sem dele ser a senhora. Ao contrário, dele, enquanto um negócio humano, ela recebe sentido e subordinação. É preciso, portanto, colocar a religião em seu divido lugar, ou seja, aquele do produto de uma cultura e de costumes ingênuos e supersticiosos, que é preciso superar. Com efeito, existe um progresso do conhecimento e dos costumes; a história possui um significado e uma direção, ela permite ao homem tornar-se sempre mais rico em conhecimentos e bem-estar. Desse modo, a ruptura entre a consciência do tempo histórico, próprio ao pensamento voltairiano, e a doutrina providencial se revela em sua maior intensidade.

Sub specie aeternitatis, nada pode constituir-se em algo verdadeiramente novo ${ }^{12}$, quer perscrutemos o futuro com a reserva do crente ou com o ar trivial do homem de ciência. A humanidade pode se mostrar mais inteligente ou mais astuta, refinada ao extremo em suas técnicas, tornar-se mais sábia ou mais prudente; no entanto, jamais a história a conduzirá às esferas novas e desconhecidas do futuro. A transmutação de um futuro profético em um futuro sob prognóstico em nenhum momento perturbou, verdadeiramente, a espera cristã: "a não realização do fim do mundo havia consolidado a Igreja e, ao mesmo tempo, sua concepção de um tempo estático percebido como tradição." (KOSELLECK, 1979, p. 33). Em conformidade a esse estado de coisas, o futuro do mundo e seu fim encontram-se integrados na própria história da Igreja, o que tem como consequência o enquadramento de toda nova profecia na rubrica heresia. ${ }^{13}$ A Igreja organizava este fim do mundo, que não chegava, de modo a poder se estabilizar como senhora do mundo sob a promessa redentora. ${ }^{14}$ 
"É necessário tomar o eschaton desconhecido como um fator de integração da Igreja, que podia, a partir desse fato, se constituir no mundo e erguer-se como instituição. A Igreja em si é escatológica. Mas, a partir do instante no qual as representações do Apocalipse segundo São João puderam ser aplicadas a acontecimentos ou a instantes concretos, a escatologia torna-se um fator de desintegração. O fim do mundo só poder ser um fator de integração, na medida em que ele permaneça não determinável sobre um plano histórico-político." (Id. ibid., p. 22).

Quando uma doutrina da providência arvora-se em tudo ver a anunciação de um poder que é essencialmente invisível, ela expõe o poder espiritual a um abuso da visibilidade, abrindo, dessa maneira, uma série de fissuras em seu discurso sobre o histórico. Mesmo respaldado pelo princípio da autoridade, esse discurso abusa na determinação providencial dos fatos: o esforço para explicar algo como o Desastre de Lisboa acaba por desgastar o que há de invisível e de garantidor daquilo que inspira a santidade da Igreja, é torná-la demasiado terrestre. A modernidade saberá localizar e usar esse desgaste a seu favor na construção de um pensamento desvinculado da redenção. A originalidade do novo pensamento sobre a história reside no fato de liberar o homem de seu próprio passado como tradição e perpetuidade da culpa e lhe mostrar a possibilidade do futuro e do progresso. $\mathrm{Na}$ medida em que o tempo se faz progresso, isto é, na medida em que ele passa a ser o palco da visibilidade das transformações do homem e que daí se pode tirar, inegavelmente, elementos positivos, ele se desacraliza, deixa de ser uma categoria escatológica. O passado é percebido e estudado em vista da compreensão do presente; do momento em que se vive, aclarado pela experiência trazida pelas anteriores gerações, aposta-se no futuro das gerações. A modernidade passa a assinalar a investida no progresso dos homens e na consecução de dias melhores: da ignorância de onde saímos, para o estado civilizado a que chegamos, eis o que nos habilita a pensar um futuro sob prognóstico.

O movimento gerado pelos homens na direção de seu aperfeiçoamento não autoriza, no entanto, a certeza na história: “Toda certeza que não é demonstração matemática é somente uma extrema probabilidade: não existe outro tipo de certeza na história." (VOLTAIRE, 1879, Article 


\section{4}

Histoire). Justamente por se tratar de um movimento humano, ela está sujeita ao limite racional e ao reino da probabilidade.

"Voltaire acredita num progresso limitado e não encorajará desmesuradas esperanças. Para ele, o século dezoito havia atingindo um estado quase ideal. Só a luta contra a Igreja e contra a superstição cristã deveria ainda chegar a termo." (BULTMANN, 1959, p. 94).

O terreno da história, se é o campo de aprendizagem, é, do mesmo modo, uma área que requer a investida prudente, pois essa aprendizagem está acompanhada de uma série de tarefas que não permite uma acomodação do homem a um plano providencial, por exemplo, mas o testa com o objetivo de reconhecer seus limites e, dessa forma, poder aperfeiçoar-se. Voltaire preserva a especulação acerca das épocas remotas, sobre as quais nos faltam documentos suficiente que possam autorizar a falar sobre elas:

"Sou tão ignorante que não sei mesmo os fatos antigos com os quais me iludem. (...) Toda a antiguidade é tão tenebrosa até Tucídides e Xenofontes que sou reduzido a não saber quase nada do que se passou sobre o globo que habito antes do curto espaço de mais ou menos 30 séculos; e nesses trinta séculos quanta obscuridade, quanta incerteza, quanta fábula!” (VOLTAIRE, 1961, p. 909).

O mesmo se passa quando consultamos as fontes sagradas: "Se nossas Santas Escrituras disseram que o Chaos existia, se o Tohu Bohu foi adotado por ela, nisso cremos, sem dúvida, e com a mais viva fé. Falamos aqui apenas segundo os lampejos enganadores de nossa razão. Somos limitados, como dissemos, a ver o que podemos supor por nós mesmos. Somos crianças que tentam dar alguns passos sem andadeiras: caminhamos, caímos e a fé nos soergue." (VOLTAIRE, 1961, pp.871-872).

A recusa é a de conhecer um homem anterior ao homem, e a busca das origens conduz-nos muito mais ao reconhecimento do insuportável orgulho da razão, do que a uma lição histórica útil. O homem pensa sob a perspectiva do finito: como, sendo histórico, poderia ele falar, de modo pertinente, sobre uma origem da história ou do infinito histórico? "Inesperadamente", diz Voltaire, 
“sinto-me estacado em minha vã curiosidade. Miserável mortal, se não posso sondar minha própria inteligência, se não posso saber o que a anima, como conhecerei a inteligência inefável que preside visivelmente a matéria inteira? Essa inteligência é infinita em potência e em imensidão como é incontestavelmente infinita em duração? Por mim mesmo, disso nada posso saber. (...) qual ideia posso ter de uma potência infinita? (...) O infinito em número e em extensão está fora da esfera de meu entendimento. Sinto, felizmente, que minhas dificuldades e minha ignorância não podem prejudicar a moral.” (VOLTAIRE, 1961, p. 873).

A lição metafísica do limite do entendimento também serve para as pretensões da história: nem as origens insondáveis, nem um futuro previsível infinitamente. De uma parte, Voltaire elimina a hipótese bíblica do Gênesis, de uma humanidade saída das mãos de Deus depois de seis ou sete mil anos. Daí a importância da crítica à Bíblia como fonte para a história: "Os homens não se multiplicam tão facilmente como se pensa", diz Voltaire. "Um terço das crianças morre ao final de dez anos." Todavia, "sábios cronologistas ${ }^{15}$ calcularam que uma só família, depois do dilúvio, sempre ocupada em povoar (e seus filhos ocupados no mesmo propósito), se encontrava, em duzentos e cinquenta anos, com mais habitantes do que contém hoje o universo.” (VOLTAIRE, 1963, p. 209). A descoberta da China e de sua literatura, na qual encontramos também a tradicional divisão da história do mundo em épocas e a ideia de unidade da história do mundo, abala fortemente a cronologia tradicional, baseada, em grande parte, nas declarações bíblicas:

"Os Chineses inventaram um ciclo, um cômputo, que começa dois mil seiscentos e dois anos antes do nosso. Caberá a nós contestar uma cronologia unanimemente aceita entre eles, nós que possuímos sessenta sistemas diferentes para contar os tempos antigos e que, assim, não temos nenhum?" (Id. ibid., p. 208).

De outra parte, tendo largamente aberto a perspectiva dos séculos, ele reconhece em todos os tempos e lugares o mesmo homem, a fim de se sentir totalmente legitimado em seu interesse de retornar, sem prejulgamentos e ilusões, ao único tempo que conta verdadeiramente: o tempo presente. A história sob o prisma voltairiano é colocada como problema 
e não como dogmática com características de uma aquisição definitiva. $\mathrm{O}$ problema histórico é o de compreender o mundo atual: "comecemos por examinar se o globo que nós habitamos era outrora tal como é hoje." (Id. ibid., p. 3). Diz, ainda, no prefácio ao Essai sur les Moeurs:

"o alvo deste trabalho não é o de saber em qual ano um príncipe indigno de ser conhecido sucederá outro príncipe numa nação grosseira. Se conseguirmos ter a infelicidade de colocar em sua cabeça a sucessão cronológica de todas as dinastias, unicamente teremos palavras. Ao contrário, é preciso conhecer as grandes ações dos soberanos que têm conseguido tornar seus povos melhores e mais felizes, de outra forma podemos ignorar o vulgar dos reis, que só pode sobrecarregar a memória." (Id. ibid., p. 195).

O historiador não deve se preocupar com detalhes frívolos que funcionam como perfumaria na construção das imagens dos grandes personagens históricos. Estes, aliás, devem se apresentar no registro histórico balizados pelo critério ético-político da contribuição para a felicidade e o bem-estar dos povos.

Nessa direção, a partir dos costumes, é possível conhecer o espírito dos homens e deslocar as lentes da história do seu aspecto transcendente, enfocando o gênero humano propriamente dito: "É ao gênero humano que se necessita prestar atenção na história: é aí que cada escritor pode certamente dizer homo sum; no entanto, a maior parte dos historiadores tem descrito as batalhas." (Id. ibid., p. 781). Em outro lugar, acrescenta Voltaire:

"Não se deve esperar encontrar aqui, tanto quanto no quadro dos séculos precedentes, os detalhes imensos das guerras, dos ataques de vilas tomadas e retomadas pelas armas, entregues e devolvidas pelos tratados. Mil circunstâncias interessantes para os contemporâneos se perdem sob a mira da posteridade e desaparecem para que se possa ver só os grandes acontecimentos que marcaram o destino dos impérios. Nem tudo o que se faz merece ser descrito. Ateremo-nos, em nossa descrição histórica, somente ao que merece a atenção de todos os tempos, àquilo que pode dizer do gênio e dos costumes dos homens, àquilo que pode servir de instrução e conselho para o amor à virtude, às artes e à pátria." (VOLTAIRE, 1957, pp. 619-620). 
Aquele que se dedica à seara histórica deve elevar-se acima do contingente. Não deve ser sua intenção retratar o individual, o que é produto do acidente, mas o "espírito dos tempos" e o "espírito das nações." Voltaire não se prende à simples sequência de fatos, mas se volta para o progresso da cultura e para sua organização interna em seus diversos elementos.

A idéia principal é a seguinte: conhecer o mais possível os costumes dos homens e as revoluções do espírito humano; olhar a ordem das sucessões dos reis e a cronologia apenas como guias, nunca como alvo do trabalho histórico: "Não é somente a vida de Luis XIV que pretendemos escrever", diz o autor do Século de Luis XIV, "propomo-nos um objeto muito maior. Pretendemos descrever à posteridade, não as ações de um único homem, mas o espírito dos homens num século esclarecido como nenhum outro foi." (Id. Ibid. p. 616). Se compararmos o intuito de Voltaire e aquele de Bossuet, constatamos que a mudança é considerável. Para aquele, a humanidade é mais importante do que as revoluções dinásticas e a verdadeira história não é uma relação de batalhas, mas o entendimento da marcha do espírito humano e da civilização. Ao homem é reservada a condição de "mestre da história”, pois a validação das faculdades analíticas e críticas, concentrando o conjunto de valores nas zonas mais claras da consciência, desacredita todos os componentes da realidade humana que não respondam a certa coerência e a certo rigor. Tudo o que não pode ser dito em linguagem coerente deve ser rejeitado como confuso. A política, a moral, a religião e a história são áreas que devem abandonar as vacilações que seus estatutos temerários lhe provocam. "Devemos renunciar, tanto no conhecimento histórico quanto nas ciências da natureza, às ingenuidades da teleologia." (CASSIRER, 1994, p. 294), observa Cassirer comentando Voltaire. Este último denuncia e desacredita o louvor da teleologia, que impregnou a história de causas finais. A historiografia, sob um aspecto crítico deve, de modo diferente, libertar-se daquelas causas e reconduzir-se às empíricas, a fim de prestar à história o mesmo serviço que os matemáticos prestam às ciências da natureza. Segundo essa ideia, a história é concebida como uma coleção de experiências morais realizadas pelo gênero humano, a qual, sem dúvida, seria muito mais completa se tivesse sido feita apenas por filósofos, mas que, mesmo sendo informe, ainda encerra as maiores lições de conduta. 
Em Bossuet, religião e história se complementam, de modo que a história sagrada é a mais importante; definir a história como o lugar do sagrado implica uma concepção negativa do homem, o que não faculta colocá-lo no controle de sua própria trajetória. A impossibilidade da superação da morte entrega à esperança teológica a possibilidade de pensar qualquer tipo de continuidade para a humanidade: enquanto membros do corpo de Cristo, os cristãos participam de sua vitória sobre a morte, todavia, esse triunfo só pode se dá fora do tempo e, consequentemente, fora da história. Por sua vez, a filosofia da história voltairiana exprime o espírito de uma história liberada; livre ela se encontra de uma teologia que exerce as mais acintosas afrontas à sã razão. A história deve ser escrita com o "espírito filosófico", do qual os tempos modernos veem nascer o grande impulso esclarecido e militante. Isso significa que a razão consagra-se ao aperfeiçoamento da razão pelo estudo da história, mas de uma história que sagrar a humanidade como seu objeto maior: o conhecimento do passado e os progressos do presente acordam-se segundo um ponto de vista de um homem que assume seus sucessos e aprende a interpretar seus insucessos sem que para isso transforme-se num amaldiçoado peregrino em busca da redenção e marcado pela morte ignominiosa, herança do pecado. Sem redenção, a ideia de história concebida pelo Patriarca de Ferney esquece a profecia e não se atreve a eliminar o retrocesso dos rumos históricos. Com ela, aprendemos que o progresso é uma maneira de representar a humanidade inserida num campo de batalha no qual o maior inimigo é a ignorância e a superstição, e a maior arma a razão esclarecida e autônoma.

${ }^{1}$ Cf. BRUMFITT, J. H. Voltaire historian. Oxford: Oxford Univ. Press., 1958.

${ }^{2}$ Cf. DEPRUN, J. Métaphysique. In: Dictionnaire européen des Lumières. Paris: PUF, 1997, p. 706.

${ }^{3}$ Sobre o tema, consultar POMEAU, R. La religion de Voltaire. Paris: Nizet, 1969; DAGEN, J. L'histoire de l'esprit humain dans la pensée française de Fontenelle a Condorcet. Paris: Klincksieck, 1977 (Cap.VII).

4 “O sentimento, a percepção, o pensamento sobre a história são exigidos para o desenvolvimento da filosofia das Luzes.” In: DAGEN, J. Op. cit., p. 12.

${ }^{5}$ VOLTAIRE. Essai sur les Moeurs, p. 3 (T.I). É conveniente insistir que o termo "filosofia da história", aqui utilizado para traduzir a expressão lire l'histoire en philosophe, não equivale 
exatamente ao que o século XIX chamará de filosofia da história. Para Dagen, “o século XVIII não dispõe, para essa matéria, as ferramentas filosóficas das quais nos dotou o século XIX. Ele não pode, apesar da feliz descoberta de Voltaire, recorrer à noção de 'filosofia da história'." Op. cit., p. 13.

${ }^{6}$ KOSELLECK, 1979, p. 669.Voltaire é um desses autores cujo gosto pela polêmica é indiscutível. O espírito polêmico, em seu lado de instigação ao debate e à recusa das fórmulas morais e históricas perpétuas, é característica da efervescência intelectual. Contudo, pensamentos como o de Voltaire acabam por despertar as mais encarniçadas posturas, que escapam ao caráter polêmico e beiram a condenação, como registra um escrito da época. Logo na advertência ao leitor, a mensagem é clara: "Este compêndio que obteve bastante sucesso, e cuja primeira edição esgotou-se, determinou-me a estabelecer uma segunda edição, persuadido de que se receberá com bastante prazer uma obra tão importante para desmascarar inteiramente os ímpios, os charlatões tão perigosos ao Estado e que enganaram a confiança do público mal instruído." Segundo o autor,Voltaire é um dos chefes desse grupo "perigoso". "Quase todas as suas obras exaltam a libertinagem, a independência e o materialismo. Porém, o mais triste, e que anuncia uma grande depravação, é que todo mundo as lê, todo mundo as cita, mulheres, crianças, domésticos... todos se prestam a repetir suas zombarias. (...) Fala-se sua linguagem à mesa, nas assembleias. Em resumo, as máximas de Voltaire infectaram a massa geral.” HAREL, M-M., dit le P. Élie. Voltaire, recueil des particularités curieuses de sa vie et de sa mort. Porrentruy: Chez Jean-Joseph Goetschy, Imprimeur de Son Altesse, 1782, pp. 1-2. A grande depravação vociferada pelo autor, nada mais é do que a disseminação das ideias anticlericais de Voltaire, cuja repercussão estende-se até os nossos dias. Elas frequentam as discussões eruditas, assim como as populares, e colocam em questão a antiga visão de mundo eivada de superstição e obscurantismo. É o afrontamento que acompanha a chegada das Luzes.

${ }^{7}$ Inocêncio XI foi elevado à Cadeira de São Pedro em 21 de setembro de 1676, permanecendo até 1689. Ele esteve no centro da controvérsia do galicanismo, que opõe Luís XIV à Santa Sé. O soberano francês promulgou a Déclaration des Quatre Articles, redigida por Bossuet, durante uma Assembleia de Clérigos em 1682. A declaração comporta quatro artigos, um verdadeiro manifesto gálico, que pode ser resumido como segue: 1) Pedro e seus sucessores somente receberam o poder espiritual e não dispõem de nenhum poder temporal sobre os soberanos; 2) O poder espiritual do papa está submetido à autoridade dos concílios gerais, de acordo com o Concílio de Constança; 3) As regras e costumes em vigor no Reino de França e na Igreja Galicana não podem ser violados pelo poder espiritual do papa; 4) O julgamento do papa só se tornará irreformável depois do consentimento da Igreja universal. Sobre a participação de Bossuet naquela assembléia, ver: CONSTANTIN, C. Déclaration ou les quatre articles de 1682. In: Dictionnaire de théologie catholique. Paris: Letouzey et Ané, 1924. Voltaire comenta e relata o episódio no capítulo 35 do Le Siècle de Louis XIV. Não se pode deixar de notar um certo entusiasmo em sua narrativa. Para ele, "os bispos de Roma não tiveram a menor jurisdição sobre as sociedades cristãs do império do Oriente; mas, nas ruínas do império do Ocidente, tudo foi usurpado por eles. A Igreja da França foi a única, durante longo tempo, que disputou, contra a Sé de Roma, os antigos direitos que cada bispo havia se dado, quando, após o concílio de Nicéia, a administração eclesiástica e puramente espiritual se modelou pelo governo civil e cada bispo teve sua diocese como cada distrito imperial tinha o seu." A constatação histórica serve de base contra os argumentos de autoridade evocados. A própria fonte dessa autoridade não legitima, segundo Voltaire, a pretensão política de Roma. "Certamente,

doispontos, Curitiba, São Carlos, vol. 9, n. 3, p.139-162, dezembro, 2012 
nenhum evangelho disse que um bispo da cidade de Roma poderia enviar para a França legatários a latere, com o poder de julgar, reformar, dispensar, e cobrar dinheiro do povo." In: Oeuvres historiques, p. 1033.

${ }^{8}$ AgOSTINHO. De Civitate Dei,V, 10 In: Opera Omnia (Patrologiae Latinae, 41). Paris: J-P Migne, 1841. Bossuet, por sua vez, afirma: "Esse mesmo Deus, autor do encadeamento do universo, todo poderoso por si mesmo, quis, para estabelecer a ordem, que as partes de uma tão espetacular totalidade dependessem uma das outras; esse Deus quis, da mesma forma, que o curso das coisas humanas tivessem sua seqüência e suas proporções.” In: BOSSUET. Discours sur l'histoire universelle (III, 2), p.354. O interesse em distinguir o natural do sobrenatural esteve sempre ausente da filosofia de Bossuet: tudo é providencial. O natural, não somente é permitido, mas ordenado e regulado segundo as seqüências e as proporções. Sendo o conhecimento das relações causais objeto das ciências, Deus, ao doar uma ordem fixa a essas relações no curso das coisas humanas, tornou possível nossas ciências históricas. Cf. GOYET, T. L’humanisme de Bossuet (II). Paris: Klincksieck, 1965, pp. 308-309.

${ }^{9}$ A expressão é de FERREYROLLES, G. L'influence de la conception augustinienne de l'histoire au XVIIe. Siècle. In: XVIIe. Siècle, n. 135, avril - juin, 1982, p. 240.

${ }^{10}$ Cf.VOLTAIRE. Examen important de Milord Bolingbroke ou le tombeau du fanatisme (ver capítulos X e XI). In: Mélanges, pp. 1023-1030.

${ }^{11}$ Cf.VOLTAIRE. Sermon des cinquante. In: Mélanges, p.265

12 "Embora na sequência da diversidade das épocas, proclamamos agora como um fato realizado o que fora então anunciado como acontecimento futuro, a fé, ela mesma, no entanto, não variou, nem a salvação tornou-se outra." AGOSTINHO. Epistola CII, Ad Deogratias, Quaestio Secunda, n. 12. In: Opera Omnia (Patrologiae Latinae, 33) Paris: J-P Migne, 1865. Depois do pecado não há como atribuir excelência ao novo, pois a carga positiva contida no conceito de novo, como superação e avanço, desaparece. Mesmo que encontremos no pensamento agostiniano a imagem da humanidade como a de um único homem que se desenvolve (Cf. AGOSTINHO. De Civitate Dei, X, 14.), esse desenvolvimento, ou esse "progresso", não concerne, diz Béguin, nem à relação do homem com a natureza, nem ao crescimento de seus conhecimentos intelectuais, ou mesmo de seu domínio técnico, como pensaram os defensores modernos do progresso, desligados da transcendência cristã. Trata-se de um desenvolvimento, antes de tudo, espiritual. A história à qual Agostinho reconhece um valor de "progresso" se identifica inteiramente com a história da Igreja, pois seu único fim discernível é a constituição da comunidade dos santos. (Cf. BÉGUIN, A. Pascal. Paris: Seuil, 1988, pp. 73-74). Nesse sentido, a possibilidade do "novo" apenas pode ser concebida na invisibilidade da graça: "Esta novidade, que não pode desagradar a Deus, tal como o velho homem não o pode agradar, é diferente das novidades da Terra; em se tratando das coisas do mundo, por mais novas que elas sejam, envelhecem ao durar, ao passo que este espírito novo se renova tanto mais ele dure. Nosso velho homem perece, diz São Paulo (Colossenses, 3: 9), se renovando dia a dia, e não será perfeitamente novo senão na eternidade (...).” (PASCAL. Lettre à Ch de Roannez, 5/11/1656. In: Oeuvres Completes (II). Paris: Gallimard, 1998, p. 32. (Bibliothèque de la Pléiade).

13 " Um dos princípios de soberania da Igreja romana foi guardar o controle sobre todos os visionários. Toda a visão do futuro exigia, como atesta uma decisão do quinto Concílio de Latrão (1512-1517), uma autorização da Igreja. A interdição da doutrina do Terceiro Império

doispontos, Curitiba, São Carlos, vol. 9, n. 3, p.139-162, dezembro, 2012 
de Joaquim de Fiore, o destino de Joana D'Arc, queimada viva por ter afirmado, de forma imperturbável, visões não avalizadas pela Igreja, (...) são exemplos do modo como se inibia toda a profecia pós-bíblica." (Id. ibid., p. 22).

14 "Unum vero hoc non lateat vos, carissimi, quia unus dies apud Dominum sicut mille anni, et mille anni sicut dies unus." Segunda Epístola de Pedro 3, 8. Um dia para Deus é como mil anos, e mil anos como um dia; as palavras de Pedro colocam o tempo sob o completo domínio divino e, portanto, fora da cronologia. A espera, assim, inclui algo divino porque incorpora a submissão ao Senhor do tempo e da história. O número de anos que faltam para o fim dos tempos, quem o pode saber? Trata-se de uma conjectura humana que nada anuncia de certo nem pode atestar as Escrituras. A vigilância nessa espera cabe à Igreja.Ver AGOSTINHO De Civitate Dei, XVIII, 53.

${ }^{15}$ Referência ao jesuíta Petau. Cf.VOLTAIRE. Essai sur les Moeurs. p. 86 (T.I)

\section{Referências bibliográficas}

AGOSTINHO. 1841. De Civitate Dei. In: Opera Omnia (Patrologiae Latinae, 41). Paris: J-P Migne.

BENELLI, G. 2000. Voltaire metafísico. Genova: Name.

BIZIOU, M. 1997. Essai. In: Dictionnaire européen des Lumières. Paris: P.U.F.

BOSSUET. 1966. Discours sur l'histoire universelle (III, 1). Ed. Jacques Trucher. Paris: Garnier-Flammarion.

BOSSUET, J-B. 1961. Sermon sur la Providence. In: Oeuvres. Paris: Gallimard.

BULTMANN, R. 1959. Histoire et eschatologie. Trad. de R. Brandt. Neuchâtel: Delachaux \& Niestlé.

CASSIRER, E. 1994. A Filosofia do Iluminismo.Trad. de Álvaro Cabral. Campinas: Edunicamp.

DAGEN, J. 1977. L'histoire de l'esprit humain dans la pensée française de Fontenelle a Condorcet. Paris: Klincksieck.

FERENCZI, L. 1984. Le Discours de Bossuet et l' Essai de Voltaire. In: KOVÁCS, I. Les Lumières en Hongrie, en Europe Centrale et en Europe Orientale. Budapest, Maison d'Édition de l'Academie des Sciences de Hongrie. Paris: Éditions CNRS. 
FERREYROLLES, G. 1982. L'influence de la conception augustinienne de l'histoire au XVIIe. Siècle. In: XVIIe, Siècle, n. 135, avril - juin, 1982. KOSELLECK, R. 1979. Vergangene Zukunft - Zur Semantik geschichtlicher Zeiten. Frankfurt am Main: Suhrkamp Verlag.

LÖWITH, K. Weltgeschichte und Heilsgeschehen. 1983. Die theologischen Voraussetzungen der Geschichtsphilosophie. In: Sämtliche Schriften (Band II). Stuttgart: J. B. Metzlersche Verlagsbuchhandlung.

POMEAU, R. Essai sur les Moeurs. 1963. Paris: Garnier.

VOLTAIRE. 1975. À Charles-Jean-François Hénault, 08/10/1752. In: Correspondance (v. III). Paris: Gallimard.

VOLTAIRE. 1879. Dictionnaire philosophique. In: Oeuvres complètes (v. 19) Paris: Garnier Frères.

VOLTAIRE. 1963. Essai sur les Moeurs. Paris: Garnier.

VOLTAIRE. 1961. Le Philosophe Ignorant. In: Mélanges. Paris: Gallimard.

VOLTAIRE. 1961. Poème sur le Désastre de Lisbonne. In: Mélanges. Paris: Gallimard.

VOLTAIRE. 1957. Précis du siècle de Louis XIV. In: Oeuvres historiques. Paris: Gallimard.

VOLTAIRE. 1879. Profession de foi des Théistes. In: Oeuvres Complètes (v. 27). Paris: Garnier Frères.

VOLTAIRE. 1957. Remarques sur l'histoire. In: Oeuvres historiques. Paris: Gallimard.

VOLTAIRE. 2005. Zadig. In: Contos e novelas. Trad. de Mário Quintana. São Paulo: Globo. 